\title{
Fifty years of the Journal of Agricultural Engineering
}

The Journal of Agricultural Engineering (JAE) celebrates with this issue the publication of its fiftieth volume. The Journal was founded in 1969, on the initiative of the Italian Society of Agricultural Engineering (AIIA) to publish the results of scientific and experimental acquisitions of the sector, noted the serious lack of adequate editorial venues for what was then called Génie Rural. Initially published in Italian under the name of Rivista di Ingegneria Agraria by the publisher Edagricole, it was one of the first sector journals in Europe and since 1970 it has always followed an annual periodicity, with each volume consisting of four issues printed quarterly, for a total of almost 1200 scientific papers published so far.

The first direction was entrusted to Prof. Giuseppe Pellizzi, with the collaboration of a Scientific Committee of the Editorial Board which included the president of the Society (Prof. Giuseppe Stefanelli), the coordinators of its five sections (Professors Leone, Ricci, Priorelli, Sciubba and Panerai) and a representative of the technical associations of the sector (MP Franzo, president of the UMA - Utenti Motori Agricoli).

The Number 1 of the first year, printed in March 1970, included three papers of agricultural mechanics authored by Professors De Zanche, Pellizzi and Sangiorgi, Gasparetto and Wisniewski. From the first issue all contributions submitted to the Journal were subject to anonymous peer review. The papers, published in Italian, were accompanied by a summary in English, French and German. The journal closed each issue with pages relating to a news bulletin of national and international scientific events and meetings, and of other information relevant to the agricultural engineering community.

Pellizzi's management lasted from 1970 to 1982 and was followed by that of Prof. Ettore Gasparetto, who held the office until 1993. Both the first Editors belonged to the University of Milan, while with the appointment of the next Editor, Prof. Enzo Manfredi (from 1993 to 1998), the Bolognese period of management of the Journal began. In fact, Manfredi and the next two Editors - the late Prof. Adriano Guarnieri (from 1998 to 2014) and his colleague Prof. Giovanni Molari (from 2014 to 2018) belonged to the University of Bologna.

It was in this period that the belief matured for the need for a transformation of the Journal, from a purely national to a markedly international publication. The transition took place in 2014 with the adoption of the English language as mandatory for all papers and the gradual renewal and expansion of the editorial board, up to the current structure, with a prevalence of non-Italian components. The graphic layout and the publisher also changed, from ETS to PagePress, but above all it was decided to favour the access to the Journal to a wider audience of readers, choosing to publish it both in printed and digital format and adopting the open access model for the latter (with very low publication costs).

The decision quickly turns out to be a wise one, as evidenced by the increasing number of papers submitted and published and the volume of accesses to the Journal's website: papers are quickly settled at values of about thirty a year, while accesses increase steadily, rising from 32,000 in 2015 to 55,000 in 2018, and also increases proportionally the number of papers downloaded (from about 100,000 to a peak of 170,000 ). The weight of the international component is also growing steadily: about three quarters of the visits to the site currently come from international readers, with India and the United States leading the way with a quarter of the visits each.

In 2014, JAE is indexed for the first time in the Scopus database, initially in the Q4 range in the categories Industrial and Manufacturing Engineering and Mechanical Engineering, and then quickly rise to Q3 and reach Q2, currently reaching the thresholds of the Q1 range for the first category ( $73^{\text {rd }}$ percentile).

JAE was then accepted in ESCI (the Emerging Sources Citation Index) in 2016, counting a total of 532 citations, with an $h$-index of 11 , so far.

The Journal surpasses the milestone of its first 50 years in a phase of prominent growth, which gives hope for the future. This was only possible thanks to the strong support of the AIIA, the continuous commitment of the Editorial Board and the trust of authors and readers, to whom we would all like to extend our heartfelt thanks.

It is with pride, therefore, that we celebrate 50 years of JAE, looking to the future with a renewed commitment to contribute to the dissemination of the scientific and technological contributions that the Agricultural Engineering can offer to better address the upcoming challenges of agriculture, forestry, rural areas and agroindustry.

Claudio Gandolfi and Giacomo Scarascia-Mugnozza 


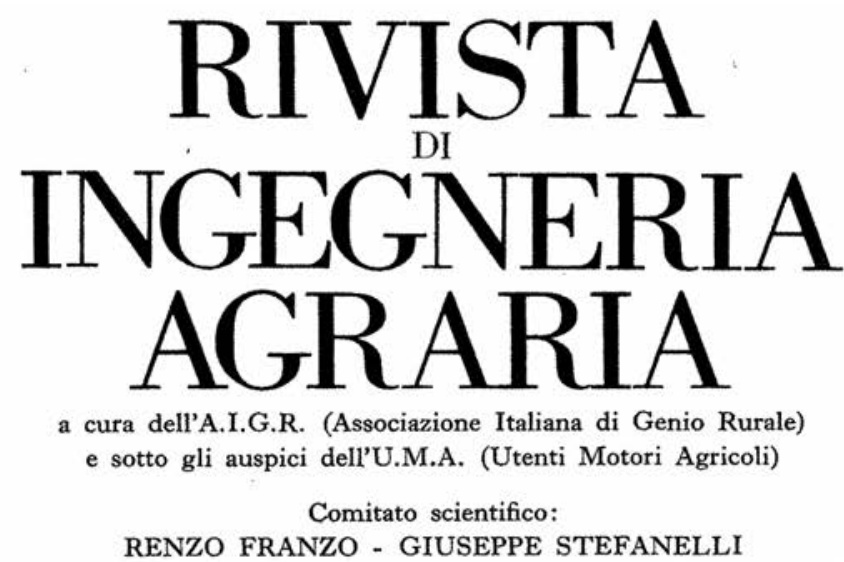

GIULIO LEONE - CORRADO RICCI - GIUSEPPE PRIORELLI - RAFFAELE SCIUBBA - ALFREDO PANERAI DIRETTORE: GIUSEPPE PELLIZZI

SEGRETARIO: LORENZO PARISI

ANNO PRIMO - NUMERO 1 - MARZO 1970

\section{S O M M A R I O}

3 Presentazione del Presidente dell' U.M.A.

5 Presentazione del Presidente dell'A.I.G.R.

Cesare De Zanche

Giuseppe Pellizzi - Franco Sangiorgi

Ettore Gasparetto - Teofil Wisniewski
7 Studio cinematico dell'apparato di taglio delle diradatrici per la barbabietola da zucchero

17 Metodologie di prova di mungitrici meccaniche, adottate in diversi paesi

33 Studio sull'impiego di una regolazione non continua del tipo «off-on» sui motori diesel

47 Notiziario dell'A.I.G.R.

49 Rassegne informative

\section{GRUPPO GIORNALISTICO DELL'EDAGRICOLE}

Figure 1. The Number 1 of the first year, printed in March 1970. 
Candura A., Gusman A., - Comportamento statico di un silo per cereali in vetroresina . . . . .

Cicogna M., Sangiongi F., - Prove di laboratorio di misuratori prelevatori per impianti di mungi-

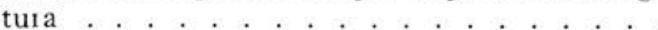

Croni A., - Ricerche di laboratorio sulla tenacità pura dei terreni... . . . . . . . . .

DE ZANChe C., - Studio cinematico dell'apparato di taglio delle diradatrici per la barbabietola da zucchero . . . . . . . . . . . . . . . .

Dipaola G., - Studio teorico sulla raccolta meccanica dell'uva ..............

Gasparetto E., Wisniewski T. - Studio sull'impiego di una regolazione non continua del tipo "off-on" sui motori diesel . . . . . . . . .

Gusman A., Candura A. - Comportamento statico di un silo per cereali in vetroresina

Montani M. - Sui cicli di raccolta del mais a maturazione cornea

Pellizzi G., Sangiorgi F. - Metodologie di prova di mungitrici meccaniche, adottate in diversi paesi . . . . . . . . . . . . .

SAngiorgi F., Cicogna M. - Prove di laboratorio di misuratori prelevatori per impianti di mungitura. . . . . . . . . . . . . . .

Sangiorgi F., - Pellizzi G. - Metodologie di prova di mungitrici meccaniche, adottate in diversi paesi . . . . . . . . . . . . .

Scotron M. - Il fabbisogno di lavoro nel vigneto specializzato . . . . . . . . . . . . . . . .

Stefanelli G. - Calcolo diretto del rendimento delle trattrici a ruote pneumatiche a due e a quattro ruote motrici .......... .

TINÈ G. - Primi risultati sperimentali sulla cernita automatica del pomodoro . . . . . . . . .

Wisniewski T., Gasparetto E. - Studio sull'impiego di una regolazione non continua del tipo "off-on» sui motori diesel . . . . . . . . .

Zoli M. - Pile a combustione: sviluppo tecnologico ed applicazioni in agricoltura . . . . . . .

Notiziario dell'A.I.G.R., 47, 109, 143, 206.

Rassegne informative, 49, 145, 212.
TINÈ G. - First experimental results in automatic selection of tomato fruits .........

175 Wisniewski T., Gasparetto E. - Research on air cooled diesel engines with an "off-on" regulation of cooling ............ . .

ZoLi M. - Fuel Cells: technological developement and agricultural applications ....... .

A.I.G.R. News, 47, 109, 143, 206.

INFORMATIONS BRIEFINGS, 49, 145, 212.

Figure 2. Table of authors and contents of the first issue of 1970. 